\title{
Conditional Cash Transfers, Resources, and Political Participation in Latin America
}

Gregory S. Schober

\section{Appendix}

Variables from the 2014 Mexican Survey Data

*Note: many survey questions are taken or adapted from the 2012 LAPOP survey

Voting: An additive index of whether the respondent has registered to vote, voted in the last presidential election, voted in the last state legislative election, and voted in the last municipal election. When necessary, survey question responses are rescaled so that larger values indicate more political participation. Also, if a survey question has multiple response categories, then it is rescaled to have a maximum value of one (Mean: 3.14 ; SD: 1.29)

Camp Activism: An additive index of whether the respondent has tried to convince others to vote, participated in an electoral campaign in the last presidential election, and attended meetings for a political party or movement in the last twelve months. When necessary, survey question responses are rescaled so that larger values indicate more political participation. Also, if a survey question has multiple response categories, then it is rescaled to have a maximum value of one (Mean: .29; SD: .45)

Cont Publ Officials: An additive index of whether the respondent has contacted a member of the legislature, contacted a local politician, contacted a state official or agency, contacted a public program official, asked for help from or presented a petition to a government official in the last twelve months, and signed a petition in the last twelve months. When necessary, survey question responses are rescaled so that larger values indicate more political participation. Also, if a survey question has multiple response categories, then it is rescaled to have a maximum value of one (Mean: 1.03; SD: 1.43) 
Comm Activism: An additive index of whether the respondent has attended a municipal meeting or session in the past twelve months, contributed to help resolve a community problem in the past twelve months, attended meetings for a community improvement group in the past twelve months, and attended neighborhood committee meetings in the past twelve months. When necessary, survey question responses are rescaled so that larger values indicate more political participation. Also, if a survey question has multiple response categories, then it is rescaled to have a maximum value of one (Mean: .47; SD: .63)

Civ Soc Engage: An additive index of how often the respondent has attended meetings for a religious organization in the last twelve months, a school organization in the last twelve months, a health organization in the last twelve months, and any other organization in the last twelve months. When necessary, survey question responses are rescaled so that larger values indicate more political participation. Also, if a survey question has multiple response categories, then it is rescaled to have a maximum value of one (Mean: .88; SD: .70)

Protest: An additive index of whether the respondent has participated in a protest or demonstration in the past twelve months, and whether the respondent has participated in a blockade in the past twelve months. When necessary, survey question responses are rescaled so that larger values indicate more political participation. Also, if a survey question has multiple response categories, then it is rescaled to have a maximum value of one (Mean: .12; SD: .41). $C C T$ : a dichotomous variable for whether someone in the household participates in the Oportunidades program: $1=$ CCT participant, $0=$ Not a CCT participant (Mean: .30; SD: .46) UCT: a dichotomous variable for whether someone in the household participates in the Programa de Apoyo Alimentario (PAL) program: 1=UCT participant, $0=$ Not a UCT participant (Mean: $.10 ;$ SD: .30) 
Income: Adding up the income from all household members that work, the range of monthly household income out of 8 categories (Mean: 3.35; SD: 1.16)

Wealth Index: this variable is measured using a household living standard index. Out of a total of twelve household items, the additive index counts the number of items in the respondent's house. The household items include cooking materials, refrigerator, land telephone, cellphone, car, washing machine, microwave, video cassette or DVD player, 3 or more rooms in the house, bathroom, computer, and internet (Mean: 4.28; SD: 2.40).

Employed: a dichotomous variable for whether the respondent is currently employed.

1=employed, $0=$ not employed (Mean: .51; SD: .50)

Education: highest level of education completed (Mean: 4.13; SD: 1.85).

Age: the natural log of the respondent's age in years (Mean: 3.66; SD: .38)

Female: a dichotomous variable for whether the respondent is female. $1=$ female, $0=$ male (Mean: .51; SD: .50).

Married: a dichotomous variable for whether the respondent is currently married. $1=y e s, 0=$ no (Mean: .75; SD: .43)

Children: a dichotomous variable for whether the respondent has children. $1=y e s, 0=$ no (Mean: $.73 ;$ SD: .44)

Religiosity: how often the respondent attends religious services: $1=$ never or almost never, $2=$ once or twice a year, $3=$ once a month, $4=$ once a week, $5=$ more than once a week (Mean: 3.28; SD: .97)

Partisanship (any party): a dichotomous variable for whether the respondent sympathizes with any political party (Mean: .31; SD: .46) 
Partisanship (PRI): a dichotomous variable for whether the respondent sympathizes with the Partido Revolucionario Institucional or PRI political party (Mean: .20; SD: .40)

Partisanship (PAN): a dichotomous variable for whether the respondent sympathizes with the Partido Acción Nacional or PAN political party (Mean: .08; SD: .27)

President Vote Choice (PRI): a dichotomous variable for whether the respondent voted for the PRI political party in the last presidential election (Mean: .70; SD: .46)

President Vote Choice (PAN): a dichotomous variable for whether the respondent voted for the PAN political party in the last presidential election (Mean: .21; SD: .41)

Population: the total population in the respondent's locality in 2010. This variable is standardized in the models (Mean: 7405; SD: 2955)

Poverty: the number of households without potable water, sewerage, or electricity in the respondent's locality divided by the total number of households in the respondent's locality in 2010 (Mean: .27; SD: .29)

Education: the total number of people with education beyond secondary school in the respondent's locality in 2010. This variable is standardized in the models (Mean: 1067; SD: 600) Attended a Meeting and Participated in the Discussion: How often the respondent has attended meetings and participated in the discussions in the past year, thinking only of their experiences at work, in social programs, or in other nonpolitical activities. $0=$ never, $1=$ one or two times a year, $2=$ one or two times a month, and 3= once a week (Mean: .43; SD: .72).

Organized a Meeting or Set Up an Appointment: How often the respondent has organized a meeting or set up an appointment in the past year, thinking only of their experiences at work, in social programs, or in other nonpolitical activities. $0=$ never, $1=$ one or two times a year, $2=$ one or two times a month, and 3= once a week (Mean: .30; SD: .58). 
Wrote a Letter or Filled Out Forms: How often the respondent has written a letter or filled out forms in the past year, thinking only of their experiences at work, in social programs, or in other nonpolitical activities. $0=$ never, $1=$ one or two times a year, $2=$ one or two times a month, and 3= once a week (Mean: .26; SD: .55).

Asked Someone to Clarify Information: How often the respondent has asked someone questions or for clarifications regarding some information in the past year, thinking only of their experiences at work, in social programs, or in other nonpolitical activities. $0=$ never, $1=$ one or two times a year, $2=$ one or two times a month, and 3= once a week (Mean: .28; SD: .55). Civic Skills Index: An additive index of the four survey questions on civic skills, with each question rescaled to have a maximum value of one and equal weight in the index (Mean: .42; SD: .58).

Govt Interested in You: Respondent's assessment of whether those who govern the country are interested in what people like her think. $0=$ strongly disagree, $1=$ somewhat disagree, $2=$ neither agree nor disagree, $3=$ somewhat agree, and 4=strongly agree. (Mean: 1.66; SD: 1.19) Vote Matters: Respondent's assessment of whether the vote influences what happens in the country. $0=$ strongly disagree, $1=$ somewhat disagree, $2=$ neither agree nor disagree, $3=$ somewhat agree, and 4=strongly agree. (Mean: 1.98; SD: 1.12)

Understand Political Issues: Respondent's assessment of whether she understands important political issues well. $0=$ strongly disagree, $1=$ somewhat disagree, $2=$ neither agree nor disagree, 3=somewhat agree, and 4=strongly agree. (Mean: 1.78; SD: .99)

Informed about Loc Govt: Respondent's assessment of whether she is better informed about local government than the majority of other people in her community. $0=$ strongly disagree, $1=$ 
somewhat disagree, $2=$ neither agree nor disagree, $3=$ somewhat agree, and $4=$ strongly agree. (Mean: 1.65; SD: .97)

Ability to Help Com Group: Respondent's assessment about whether she lacks the ability to help a community improvement group. $0=$ strongly disagree, $1=$ somewhat disagree, $2=$ neither agree nor disagree, $3=$ =somewhat agree, and 4=strongly agree. Rescaled so that larger values indicate more ability. (Mean: 2.43; SD: 1.00)

Interest in Politics: Respondent's assessment of her level of interest in politics. $0=$ none, $1=\mathrm{a}$ little, 2=some, 3=a lot. (Mean: 1.21; SD: .80)

Registered to Vote: Dichotomous variable for whether the respondent is registered to vote. $0=$ no, 1=yes (Mean: .94; SD: .23)

Voted in Last Presidential Election: Dichotomous variable for whether the respondent voted in the last presidential election. $0=$ no, $1=$ yes (Mean: .75; SD: .44)

Voted in Last State Legislative Election: Dichotomous variable for whether the respondent voted in the last state legislative election. $0=$ no, $1=$ yes (Mean: .70; SD: .46)

Voted in Last Municipal Election: Dichotomous variable for whether the respondent voted in the last municipal election. $0=$ no, $1=$ yes (Mean: .74; SD: .44)

Tried to Convince Others to Vote: Respondent's assessment of the frequency that she/he has tried to convince others to vote for a party or candidate in elections. $0=$ never, $1=$ rarely, 2=sometimes, $3=$ often (Mean: .46; SD: .74)

Participated in Electoral Campaign in Last Election: Dichotomous variable for whether the respondent worked for a party or candidate in the last presidential election. $0=$ no, $1=y e s$ (Mean: $.07 ; \mathrm{SD}: .25)$ 
Attended Meetings for a Political Party: Respondent's assessment of how often she/he attended meetings for a political party or political movement in the past year. $0=$ never, $1=1-2$ times a year, 2=1-2 times a month, $3=$ once a week (Mean: .21; SD: .50)

Contacted Member of the Legislature: Dichotomous variable for whether the respondent contacted a member of the legislature in order to ask for help. 0=no, 1=yes (Mean: .14; SD: .35) Contacted Local Politician: Dichotomous variable for whether the respondent contacted a local politician such as a municipal president or council member in order to ask for help. $0=$ no, $1=$ yes (Mean: .24; SD: .43)

Contacted State Official or Agency: Dichotomous variable for whether the respondent contacted an official or office of the state in order to ask for help. $0=$ no, $1=$ yes (Mean: .15; SD: .36)

Contacted Public Program Official: Dichotomous variable for whether the respondent contacted an Oportunidades program official or some other program official in order to ask for help. $0=$ no, 1=yes (Mean: .22; SD: .42)

Presented Petition to Govt Official: Dichotomous variable for whether the respondent asked for help or presented a petition to a government office, official, or politician in the past year. $0=$ no, 1=yes (Mean: .13; SD: .34)

Signed Petition: Dichotomous variable for whether the respondent signed a petition in the past year. $0=$ no, $1=$ yes (Mean: .17; SD: .37)

Attended Municipal Session: Dichotomous variable for whether the respondent attended a municipal meeting or session in the past year. $0=$ no, $1=$ yes (Mean: .13; SD: .33) Helped Resolve Community Problem: Respondent's assessment of how often she/he has helped to resolve a problem in the community or neighborhood in the past year. $0=$ never, $1=1-2$ times a year, 2=1-2 times a month, $3=$ once a week (Mean: .41; SD: .68) 
Attended Meetings for a Community Improvement Group: Respondent's assessment of how often she/he attended meetings for a community improvement group in the past year. $0=$ never, $1=1-2$ times a year, 2=1-2 times a month, $3=$ once a week (Mean: .32; SD: .61) Attended Neighborhood Committee Meetings: Respondent's assessment of how often she/he attended meetings for a neighborhood committee in the past year. $0=$ never, $1=1-2$ times a year, 2=1-2 times a month, $3=$ once a week (Mean: .30; SD: .59) Attended Religious Organization Meetings: Respondent's assessment of how often she/he attended meetings for a religious organization in the past year. $0=$ never, $1=1-2$ times a year, $2=1$ 2 times a month, $3=$ once a week (Mean: 1.28; SD: 1.20) Attended School Organization Meetings: Respondent's assessment of how often she/he attended meetings for a school organization for parents in the past year. $0=$ never, $1=1-2$ times a year, $2=1$ 2 times a month, $3=$ once a week (Mean: .75; SD: .89) Attended Health Organization Meetings: Respondent's assessment of how often she/he attended meetings for an organization dedicated to health in the past year. $0=$ never, $1=1-2$ times a year, 2=1-2 times a month, $3=$ once a week (Mean: .44; SD: .74) Attended Meetings for Any Other Organization: Respondent's assessment of how often she/he attended meetings for any other organization or civic association in the past year. $0=$ never, $1=1-2$ times a year, 2=1-2 times a month, $3=$ once a week (Mean: .17; SD: .45) Participated in a Protest: Dichotomous variable for whether the respondent participated in a demonstration or protest in the past year. $0=$ no, $1=$ yes (Mean: .06; SD: .23) Participated in a Blockade: Dichotomous variable for whether the respondent participated in a blockade in the past year. $0=$ no, $1=$ yes (Mean: .06; SD: .24) 
Electoral Political Participation: Additive index of all activities from the Voting Index and the Campaign Activism Index. Each activity is rescaled so it has equal weight in the index and a maximum value of one (Mean: 3.28; SD: 1.53)

Non-Electoral Political Participation: Additive index of all activities from the Contacting Public Officials, Community Activism, Civil Society Engagement, and Protest Indices. Each activity is rescaled so it has equal weight in the index and a maximum value of one (Mean: 2.60; SD: 2.39) Contact Public Officials (alternative measure): An additive index of whether the respondent has contacted a member of the legislature, contacted a local politician, asked for help from or presented a petition to a government official in the last twelve months, and signed a petition in the last twelve months. When necessary, survey question responses are rescaled so that larger values indicate more political participation. Also, if a survey question has multiple response categories, then it is rescaled to have a maximum value of one (Mean: .67; SD: .99) Community Activism (alternative measure): An additive index of whether the respondent has attended a municipal meeting or session in the past twelve months and attended neighborhood committee meetings in the past twelve months. When necessary, survey question responses are rescaled so that larger values indicate more political participation. Also, if a survey question has multiple response categories, then it is rescaled to have a maximum value of one (Mean: .23; SD: .40)

Civil Society Engage (alternative measure): An additive index of how often the respondent has attended meetings for a religious organization in the last twelve months and any other organization in the last twelve months. When necessary, survey question responses are rescaled so that larger values indicate more political participation. Also, if a survey question has multiple response categories, then it is rescaled to have a maximum value of one (Mean: .48; SD: .44) 
Civic Skills Index (alternative measure): An additive index of two of the survey questions on civic skills (organized a meeting or set up an appointment, and asked someone to clarify information), with each question rescaled to have a maximum value of one and equal weight in the index (Mean: .10; SD: .16)

\section{Variables from the 2012 LAPOP Survey Data}

Voting: An additive index of whether the respondent has registered to vote, voted in the last presidential election, and would vote in the current presidential election. When necessary, survey question responses are rescaled so that larger values indicate more political participation. Also, if a survey question has multiple response categories, then it is rescaled to have a maximum value of one (Mean: 2.55; SD: .80)

Campaign Activism: An additive index of whether the respondent has tried to convince others to vote, participated in an electoral campaign in the last presidential election, and attended meetings for a political party or movement. When necessary, survey question responses are rescaled so that larger values indicate more political participation. Also, if a survey question has multiple response categories, then it is rescaled to have a maximum value of one (Mean: .32; SD: .55) Contacting Public Officials: An additive index of whether the respondent has contacted a member of the legislature, contacted a local politician, contacted a state official or agency, asked for help from or presented a petition to a government official in the last twelve months, and signed a petition in the last twelve months. When necessary, survey question responses are rescaled so that larger values indicate more political participation. Also, if a survey question has multiple response categories, then it is rescaled to have a maximum value of one (Mean: .48; SD: .91) 
Community Activism: An additive index of whether the respondent has attended a municipal meeting or session in the past twelve months, contributed to help resolve a community problem in the past twelve months, attended meetings for a community improvement group, and organized with neighbors against crime in the last twelve months. When necessary, survey question responses are rescaled so that larger values indicate more political participation. Also, if a survey question has multiple response categories, then it is rescaled to have a maximum value of one (Mean: .56; SD: .77)

Civil Society Engagement: An additive index of how often the respondent attends meetings for a religious organization, a school organization, a professional organization, and a sports group. When necessary, survey question responses are rescaled so that larger values indicate more political participation. Also, if a survey question has multiple response categories, then it is rescaled to have a maximum value of one (Mean: .82; SD: .71)

Protest: An additive index of whether the respondent has participated in a protest or demonstration in the past twelve months, and whether the respondent has participated in a blockade in the past twelve months. When necessary, survey question responses are rescaled so that larger values indicate more political participation. Also, if a survey question has multiple response categories, then it is rescaled to have a maximum value of one (Mean: .09; SD: .36). $C C T$ : a dichotomous variable for whether someone in the household participates in the CCT program: $1=\mathrm{CCT}$ participant, $0=$ Not a CCT participant (Mean: .18; SD: .38) $U C T$ : a dichotomous variable for whether someone in the household receives government assistance each month in the form of money or products, and whether the household is below the poverty line. To determine which households are below the poverty line, I first identified the percentage living in poverty (measured as living on less than $\$ 3.10$ a day) in each country 
according to 2011 World Bank data (povertydata.worldbank.org/poverty/region/LAC). Then, for each country, I compared the percentage living in poverty with the income distribution from the corresponding LAPOP survey, and I selected the survey respondents from the lowest set of income categories that cumulatively did not exceed the poverty percentage in that country. CCT beneficiaries are recoded so that they do not count as UCT beneficiaries: $1=$ UCT participant, $0=$ Not a UCT participant (Mean: .02; SD: .14)

Income: the range of monthly household income for the respondent, including income from remittances and all adults and children in the house that work, out of 16 possible categories (Mean: 7.80; SD: 4.07)

Wealth Index: this variable is measured using a household living standard index. Out of a total of fifteen household items, the additive index counts the number of items in the respondent's house. The household items include a TV, refrigerator, land telephone, cellphone, car, washer, microwave, motorcycle, potable water, bathroom, computer, internet, flat screen TV, and sewerage (Mean: 8.69; SD: 3.15).

Education: the number of years of schooling for the respondent (Mean: 9.76; SD: 4.26).

Age: the natural log of the respondent's age in years (Mean: 3.64; SD: .40)

Female: a dichotomous variable for whether the respondent is female. $1=$ female, $0=$ male (Mean: .52 ; SD: .50).

Children: a dichotomous variable for whether the respondent has children. $1=\mathrm{yes}, 0=$ no (Mean $.73 ;$ SD: .44).

Religiosity: how often the respondent attends religious services: $1=$ never or almost never, $2=$ once or twice a year, $3=$ once a month, $4=$ once a week, $5=$ more than once a week (Mean: $2.90 ; \mathrm{SD}=$ 1.40). 
Population: a dichotomous variable for whether the respondent lives in an urban area, using the census definition in each country. $1=$ urban, $0=$ not urban (Mean: .76; SD: .42).

Registered to Vote: Dichotomous variable for whether the respondent is registered to vote. $0=$ no, 1=yes (Mean: .92; SD: .27)

Voted in Last Presidential Election: Dichotomous variable for whether the respondent voted in the last presidential election. $0=$ no, $1=$ yes (Mean: .78; SD: .42)

Would Vote in Current Presidential Election: Dichotomous variable for whether respondent would vote in current presidential election. $0=$ no, $1=$ yes (Mean: .84; SD: .37)

Tried to Convince Others to Vote: Respondent's assessment of the frequency that she/he has tried to convince others to vote for a party or candidate in elections. $0=$ never, $1=$ rarely, 2=sometimes, $3=$ often (Mean: .55; SD: .91)

Participated in Electoral Campaign in Last Election: Dichotomous variable for whether the respondent worked for a party or candidate in the last presidential election. $0=$ no, $1=$ yes (Mean: $.08 ;$ SD: .27)

Attended Meetings for a Political Party: Respondent's assessment of how often she/he attended meetings for a political party or political movement in the past year. $0=$ never, $1=1-2$ times a year, 2=1-2 times a month, 3=once a week (Mean: .17; SD: .55)

Contacted Member of the Legislature: Dichotomous variable for whether the respondent contacted a member of the legislature in order to ask for help. 0=no, 1=yes (Mean: .05; SD: .21) Contacted Local Politician: Dichotomous variable for whether the respondent contacted a local politician in order to ask for help. $0=$ no, $1=$ yes (Mean: .12; SD: .33)

Contacted State Official: Dichotomous variable for whether the respondent contacted an official or office of the state in order to ask for help. 0=no, 1=yes (Mean: .08; SD: .28) 
Presented Petition: Dichotomous variable for whether the respondent asked for help or presented a petition to a government office, official, or politician in the past year. $0=$ no, $1=$ yes (Mean: .12; SD: .33)

Signed Petition: Dichotomous variable for whether the respondent signed a petition in the past year. $0=$ no, $1=$ yes $($ Mean: .10; SD: .30)

Attended Municipal Session: Dichotomous variable for whether the respondent attended a municipal meeting or session in the past year. 0=no, 1=yes (Mean: .09; SD: .28) Helped Resolve Community Problem: Respondent's assessment of how often she/he has helped to resolve a problem in the community or neighborhood in the past year. $0=$ never, $1=1-2$ times a year, 2=1-2 times a month, $3=$ once a week (Mean: .50; SD: .82)

Attended Meetings for a Community Improvement Group: Respondent's assessment of how often she/he attended meetings for a community improvement group in the past year. $0=$ never, $1=1-2$ times a year, 2=1-2 times a month, 3=once a week (Mean: .35; SD: .75) Organized with Neighbors Against Crime: Dichotomous variable for whether respondent organized with neighbors against crime in the past year. 0=no, 1=yes (Mean: .19; SD: .40) Attended Religious Organization Meetings: Respondent's assessment of how often she/he attended meetings for a religious organization in the past year. $0=$ never, $1=1-2$ times a year, $2=1$ 2 times a month, $3=$ once a week (Mean: 1.22; SD: 1.28) Attended School Organization Meetings: Respondent's assessment of how often she/he attended meetings for a school organization for parents in the past year. $0=$ never, $1=1-2$ times a year, $2=1$ 2 times a month, $3=$ once a week (Mean: .61; SD: .90) 
Attended Professional Organization Meetings: Respondent's assessment of how often she/he attended meetings for a professional organization in the past year. $0=$ never, $1=1-2$ times a year, 2=1-2 times a month, $3=$ once a week (Mean: .18; SD: .57)

Attended Sports Group Meetings: Respondent's assessment of how often she/he attended meetings for a sports group in the past year. $0=$ never, $1=1-2$ times a year, $2=1-2$ times a month, 3=once a week (Mean: .44; SD: .94)

Participated in Protest: Dichotomous variable for whether the respondent participated in a demonstration or protest in the past year. $0=$ no, $1=$ yes (Mean: .07; SD: .26)

Participated in Blockade: Dichotomous variable for whether the respondent participated in a blockade in the past year. $0=$ no, $1=$ yes (Mean: .02; SD: .15)

Electoral Political Participation: Additive index of all activities from the Voting Index and the Campaign Activism Index. Each activity is rescaled so it has equal weight in the index and a maximum value of one (Mean: 2.89; SD: 1.04)

Non-Electoral Political Participation: Additive index of all activities from the Contacting Public Officials, Community Activism, Civil Society Engagement, and Protest Indices. Each activity is rescaled so it has equal weight in the index and a maximum value of one (Mean: 1.93; SD: 1.83) Contact Public Officials (alternative measure): An additive index of whether the respondent has contacted a member of the legislature, contacted a local politician, asked for help from or presented a petition to a government official in the last twelve months, and signed a petition in the last twelve months. When necessary, survey question responses are rescaled so that larger values indicate more political participation. Also, if a survey question has multiple response categories, then it is rescaled to have a maximum value of one (Mean: .39; SD: .77) 
Community Activism (alternative measure): An additive index of whether the respondent has attended a municipal meeting or session in the past twelve months and organized with neighbors against crime in the past twelve months. When necessary, survey question responses are rescaled so that larger values indicate more political participation. Also, if a survey question has multiple response categories, then it is rescaled to have a maximum value of one (Mean: .28; SD: .51) Civil Society Engage (alternative measure): An additive index of how often the respondent has attended meetings for a religious organization, professional organization, and sports group in the last twelve months. When necessary, survey question responses are rescaled so that larger values indicate more political participation. Also, if a survey question has multiple response categories, then it is rescaled to have a maximum value of one (Mean: .61; SD: .59) 
Table A1: Baseline Characteristics of New CCT Beneficiaries and Nonbeneficiaries (2014 Mexican Survey Data)

\begin{tabular}{lccc}
\hline & $\begin{array}{c}\text { New CCT } \\
\text { Beneficiaries } \\
\text { (mean) }\end{array}$ & $\begin{array}{c}\text { Nonbeneficiaries } \\
\text { (mean) }\end{array}$ & $\begin{array}{c}\text { Difference in } \\
\text { Means }\end{array}$ \\
\hline Income & 3.105 & 3.375 & -0.270 \\
Wealth Index & 4.146 & 4.405 & -0.259 \\
Employed & 0.463 & 0.509 & -0.046 \\
Education & 3.854 & 4.302 & -0.448 \\
Age & 38.000 & 41.952 & -3.952 \\
Female & 0.610 & 0.500 & 0.110 \\
Married & 0.780 & 0.733 & 0.047 \\
Religiosity & 3.590 & 3.250 & 0.340 \\
Partisanship (any party) & 0.317 & 0.301 & 0.016 \\
Partisanship (PRI) & 0.171 & 0.194 & -0.023 \\
Partisanship (PAN) & 0.098 & 0.083 & 0.015 \\
President Vote Choice (PRI) & 0.731 & 0.685 & 0.046 \\
President Vote Choice (PAN) & 0.269 & 0.210 & 0.059 \\
Population (locality) & 7710.512 & 7732.690 & -22.178 \\
Observations (total): 827 & & & \\
\hline$*$ p<.10, **p<.05, ***p<.01 & & \\
Notes: T-tests, Wilcoxon-Mann-Whitney tests, Chi-square tests, and Fisher's exact tests are used in \\
this analysis. The group means and the difference in group means are presented for illustration \\
purposes; the corresponding test determines significance for each variable. New program \\
beneficiaries are defined as program recipients with less than one year of participation in the \\
program. & & & \\
& & & \\
\hline
\end{tabular}


Table A2: Baseline Characteristics of New CCT and New UCT Beneficiaries (2014 Mexican Survey Data)

\begin{tabular}{lccc}
\hline & $\begin{array}{c}\text { New CCT } \\
\text { Beneficiaries } \\
\text { (mean) }\end{array}$ & $\begin{array}{c}\text { New UCT } \\
\text { Beneficiaries } \\
\text { (mean) }\end{array}$ & $\begin{array}{c}\text { Difference in } \\
\text { Means }\end{array}$ \\
\hline Income & 3.105 & 2.955 & 0.150 \\
Wealth Index & 4.146 & 3.840 & 0.306 \\
Employed & 0.463 & 0.400 & 0.063 \\
Education & 3.854 & 3.760 & 0.094 \\
Age & 38.000 & 39.240 & -1.240 \\
Female & 0.610 & 0.560 & 0.050 \\
Married & 0.780 & 0.760 & 0.020 \\
Religiosity & 3.590 & 3.080 & 0.510 \\
Partisanship (any party) & 0.317 & 0.280 & 0.037 \\
Partisanship (PRI) & 0.171 & 0.240 & -0.069 \\
Partisanship (PAN) & 0.098 & 0.040 & 0.058 \\
President Vote Choice (PRI) & 0.731 & 0.929 & -0.198 \\
President Vote Choice (PAN) & 0.269 & 0.071 & 0.198 \\
Population (locality) & 7710.512 & 7397.360 & 313.152 \\
Observations (total): 66 & & & \\
\hline *p<.10, **p<.05, ***p<.01 & & \\
Notes: T-tests, Wilcoxon-Mann-Whitney tests, Chi-square tests, and Fisher's exact tests are used in \\
this analysis. The group means and the difference in group means are presented for illustration \\
purposes; the corresponding test determines significance for each variable. New program \\
beneficiaries are defined as program recipients with less than one year of participation in the \\
program. & & & \\
& & & \\
\hline
\end{tabular}


Table A3: Confirmatory Factor Analysis Results for the Political Participation Indices (2014 Survey Data from Mexico)

\begin{tabular}{|c|c|c|c|c|c|}
\hline & Voting & $\begin{array}{l}\text { Campaign } \\
\text { Activism }\end{array}$ & $\begin{array}{l}\text { Contacting } \\
\text { Public } \\
\text { Officials }\end{array}$ & $\begin{array}{l}\text { Community } \\
\text { Activism }\end{array}$ & $\begin{array}{l}\text { Civil Society } \\
\text { Engagement }\end{array}$ \\
\hline RMSEA & .00 & .00 & .03 & .02 & .08 \\
\hline CFI & 1.00 & 1.00 & .92 & .99 & .90 \\
\hline $\mathrm{N}$ & 1093 & 1126 & 1128 & 1125 & 1126 \\
\hline \multicolumn{6}{|c|}{$\begin{array}{l}\text { Notes: The two variables in the protest index (participation in a protest and } \\
\text { participation in a blockade) are not able to be assessed using confirmatory factor } \\
\text { analysis, because all respondents who participated in a blockade also participated in a } \\
\text { protest. }\end{array}$} \\
\hline
\end{tabular}


Table A4: Multilevel Models of Voting (2014 Mexican Survey Data)

\begin{tabular}{|c|c|c|c|c|}
\hline & (1) & (2) & (3) & (4) \\
\hline & $\begin{array}{l}\text { Registered } \\
\text { to Vote }\end{array}$ & $\begin{array}{l}\text { Voted in } \\
\text { Last } \\
\text { Presidential } \\
\text { Election }\end{array}$ & $\begin{array}{l}\text { Voted in } \\
\text { Last State } \\
\text { Legislative } \\
\text { Election }\end{array}$ & $\begin{array}{l}\text { Voted in } \\
\text { last } \\
\text { Municipal } \\
\text { Election }\end{array}$ \\
\hline \multicolumn{5}{|c|}{ Individual Variables } \\
\hline $\mathrm{CCT}$ & 0.581 & 0.218 & 0.233 & $0.363 *$ \\
\hline UCT & 0.653 & $0.459 *$ & $0.509 *$ & $0.509 *$ \\
\hline Income & $0.304 * *$ & 0.097 & 0.064 & 0.098 \\
\hline Education & 0.093 & 0.052 & 0.021 & 0.003 \\
\hline Age & $2.821 * * *$ & $1.900 * * *$ & $1.675 * * *$ & $1.634 * * *$ \\
\hline Female & $0.913 * * *$ & 0.055 & -0.064 & 0.062 \\
\hline Children & -0.618 & 0.313 & 0.103 & 0.071 \\
\hline Religiosity & 0.070 & 0.027 & -0.109 & 0.011 \\
\hline \multicolumn{5}{|l|}{ Locality Variables } \\
\hline Population & $0.583 * * *$ & 0.040 & -0.183 & -0.057 \\
\hline Poverty & -0.680 & $-1.020 * * *$ & -0.367 & $-0.941 * *$ \\
\hline Education & $-0.697 * * *$ & -0.067 & 0.112 & 0.051 \\
\hline N (individual) & 954 & 945 & 932 & 938 \\
\hline $\mathrm{N}$ (locality) & 20 & 20 & 20 & 20 \\
\hline N (municipality) & 3 & 3 & 3 & 3 \\
\hline \multicolumn{5}{|c|}{$\begin{array}{l}* \mathrm{p}<.10, * * \mathrm{p}<.05, * * * \mathrm{p}<.01 \\
\text { Notes: Random-intercept multilevel logistic regression models are used in } \\
\text { this analysis. }\end{array}$} \\
\hline
\end{tabular}


Table A5: Multilevel Models of Campaign Activism (2014 Mexican Survey Data)

\begin{tabular}{llll}
\hline & $(1)$ & $(2)$ & $(3)$ \\
& $\begin{array}{l}\text { Tried to } \\
\text { Convince } \\
\text { Others to Vote }\end{array}$ & $\begin{array}{l}\text { Participated in } \\
\text { Electoral } \\
\text { Campaign in } \\
\text { Last Election }\end{array}$ & $\begin{array}{l}\text { Attended } \\
\text { Meetings for a } \\
\text { Political Party }\end{array}$ \\
\hline Individual Variables & & & \\
CCT & 0.010 & $-0.685^{*}$ & 0.038 \\
UCT & -0.028 & 0.154 & -0.026 \\
Income & $0.094^{* * *}$ & $0.413^{* * *}$ & $0.025^{*}$ \\
Education & 0.004 & 0.058 & -0.005 \\
Age & $0.133^{*}$ & 0.571 & 0.019 \\
Female & $0.103^{* *}$ & $-0.485^{*}$ & -0.026 \\
Children & 0.084 & 0.114 & -0.002 \\
Religiosity & $-0.049^{*}$ & 0.073 & 0.015 \\
Locality Variables & & & \\
Population & $0.077^{*}$ & $0.783^{*}$ & -0.024 \\
Poverty & 0.141 & 0.300 & 0.021 \\
Education & $-0.082^{*}$ & $-1.065^{* *}$ & -0.027 \\
\hline N (individual) & 953 & 955 & 955 \\
$\mathrm{~N}$ (locality) & 20 & 20 & 20 \\
$\mathrm{~N}$ (municipality) & 3 & 3 & 3 \\
\hline *p<.10, **p<.05, ***p<.01 & & \\
Note: Random-intercept multilevel logistic regression models and random- \\
intercept multilevel linear regression models are used in this analysis. \\
\hline
\end{tabular}


Table A6: Multilevel Models of Contacting Public Officials (2014 Mexican Survey Data)

(1)

(2)

(3)

(4)

(5)

(6)

\begin{tabular}{lllllll} 
& $\begin{array}{l}\text { Contacted } \\
\text { Member of } \\
\text { the } \\
\text { Legislature }\end{array}$ & $\begin{array}{l}\text { Contacted } \\
\text { Local } \\
\text { Politician }\end{array}$ & $\begin{array}{l}\text { Contacted } \\
\text { State } \\
\text { Official } \\
\text { or Agency }\end{array}$ & $\begin{array}{l}\text { Contacted } \\
\text { Public } \\
\text { Program } \\
\text { Official }\end{array}$ & $\begin{array}{l}\text { Presented } \\
\text { Petition } \\
\text { to Govt } \\
\text { Official }\end{array}$ & $\begin{array}{l}\text { Signed } \\
\text { Petition }\end{array}$ \\
\hline Individual Variables & & & & & & \\
CCT & $0.528^{* *}$ & $0.514^{* * *}$ & 0.256 & $0.359^{*}$ & -0.038 & 0.110 \\
UCT & 0.446 & 0.337 & 0.214 & 0.339 & -0.191 & 0.040 \\
Income & 0.056 & 0.082 & 0.111 & 0.079 & -0.052 & 0.115 \\
Education & -0.021 & -0.067 & 0.057 & 0.016 & 0.006 & -0.093 \\
Age & -0.189 & 0.018 & 0.425 & 0.019 & $0.582^{*}$ & 0.103 \\
Female & -0.014 & 0.136 & 0.220 & $0.448 * * *$ & 0.175 & -0.029 \\
Children & 0.236 & 0.208 & 0.347 & 0.255 & $0.465 *$ & $0.542^{* *}$ \\
Religiosity & 0.020 & -0.085 & $-0.261 * *$ & -0.112 & 0.015 & -0.064 \\
Locality Variables & & & & & & \\
Population & 0.304 & 0.213 & -0.219 & -0.127 & -0.122 & 0.096 \\
Poverty & $-1.777^{*}$ & -0.847 & -0.461 & 0.318 & 0.581 & $-0.787^{*}$ \\
Education & -0.700 & -0.321 & 0.115 & -0.133 & 0.173 & -0.171 \\
\hline N (individual) & 956 & 958 & 956 & 956 & 958 & 955 \\
N (locality) & 20 & 20 & 20 & 20 & 20 & 20 \\
N (municipality) & 3 & 3 & 3 & 3 & 3 & 3 \\
\hline
\end{tabular}

$* \mathrm{p}<.10, * * \mathrm{p}<.05, * * * \mathrm{p}<.01$

Note: Random-intercept multilevel logistic regression models are used in this analysis. 
Table A7: Multilevel Models of Community Activism (2014 Mexican Survey Data)

(1)

\begin{tabular}{|c|c|c|c|c|}
\hline & $\begin{array}{l}\text { Attended } \\
\text { Municipal } \\
\text { Session }\end{array}$ & $\begin{array}{l}\text { Helped } \\
\text { Resolve } \\
\text { Community } \\
\text { Problem }\end{array}$ & $\begin{array}{l}\text { Attended } \\
\text { Meetings for } \\
\text { a Community } \\
\text { Improvement } \\
\text { Group }\end{array}$ & $\begin{array}{l}\text { Attended } \\
\text { Neighborhood } \\
\text { Committee } \\
\text { Meetings }\end{array}$ \\
\hline \multicolumn{5}{|c|}{ Individual Variables } \\
\hline $\mathrm{CCT}$ & 0.351 & 0.023 & $0.140 * * *$ & $0.090 * *$ \\
\hline UCT & 0.077 & 0.008 & 0.032 & -0.065 \\
\hline Income & 0.060 & -0.003 & $0.035 * *$ & 0.014 \\
\hline Education & -0.005 & 0.019 & $-0.024 *$ & 0.001 \\
\hline Age & 0.239 & 0.061 & 0.017 & -0.018 \\
\hline Female & 0.076 & -0.022 & -0.008 & -0.053 \\
\hline Children & 0.068 & $0.123 * *$ & 0.078 & $0.114 * *$ \\
\hline Religiosity & 0.082 & -0.027 & 0.016 & 0.031 \\
\hline \multicolumn{5}{|l|}{ Locality Variables } \\
\hline Population & 0.016 & -0.016 & -0.041 & -0.049 \\
\hline Poverty & 0.651 & $0.314^{*}$ & 0.266 & $0.351 *$ \\
\hline Education & 0.058 & 0.047 & 0.030 & 0.031 \\
\hline $\mathrm{N}$ (individual) & 957 & 953 & 956 & 952 \\
\hline N (locality) & 20 & 20 & 20 & 20 \\
\hline $\mathrm{N}$ (municipality) & 3 & 3 & 3 & 3 \\
\hline \multicolumn{5}{|c|}{$* \mathrm{p}<.10, * * \mathrm{p}<.05, * * * \mathrm{p}<.01$} \\
\hline
\end{tabular}


Table A8: Multilevel Models of Civil Society Engagement (2014 Mexican Survey Data)

\begin{tabular}{lllll}
\hline & $(1)$ & $(2)$ & $(3)$ & $(4)$ \\
& $\begin{array}{l}\text { Attended } \\
\text { Religious } \\
\text { Organization } \\
\text { Meetings }\end{array}$ & $\begin{array}{l}\text { Attended } \\
\text { School } \\
\text { Organization } \\
\text { Meetings }\end{array}$ & $\begin{array}{l}\text { Attended } \\
\text { Health } \\
\text { Organization } \\
\text { Meetings }\end{array}$ & $\begin{array}{l}\text { Attended } \\
\text { Meetings for } \\
\text { Any Other } \\
\text { Organization }\end{array}$ \\
\hline Individual Variables & & & & \\
CCT & 0.056 & 0.106 & $0.317 * * *$ & $0.069^{* *}$ \\
UCT & -0.089 & 0.078 & 0.029 & 0.010 \\
Income & -0.022 & -0.001 & 0.010 & 0.004 \\
Education & 0.004 & 0.007 & 0.000 & 0.000 \\
Age & 0.160 & $-0.263 * * *$ & 0.042 & -0.041 \\
Female & 0.029 & $0.158^{* * *}$ & $0.203 * * *$ & $-0.115^{* * *}$ \\
Children & $0.159 *$ & $0.360 * * *$ & $0.164 * * *$ & $0.067 *$ \\
Religiosity & $0.400 * * *$ & $0.080^{* * *}$ & 0.017 & 0.011 \\
Locality Variables & & & & \\
Population & -0.148 & 0.045 & 0.068 & 0.012 \\
Poverty & 0.045 & -0.077 & 0.058 & -0.004 \\
Education & 0.016 & $-0.088^{*}$ & -0.054 & -0.027 \\
\hline N (individual) & 958 & 952 & 954 & 952 \\
N (locality) & 20 & 20 & 20 & 20 \\
N (municipality) & 3 & 3 & 3 & 3 \\
\hline$*$ p<.10, **p<.05, ***p<.01 & & & \\
Notes: Random-intercept multilevel linear regression & models are used in this analysis. \\
\hline
\end{tabular}


Table A9: Multilevel Models of Protest (2014 Mexican Survey Data)

\begin{tabular}{lll}
\hline & $(1)$ & $\begin{array}{l}(2) \\
\text { Participated }\end{array}$ \\
& $\begin{array}{l}\text { Participated } \\
\text { in a Protest }\end{array}$ & $\begin{array}{l}\text { in a } \\
\text { Blockade }\end{array}$ \\
\hline Individual Variables & & \\
$\mathrm{CCT}$ & $0.566^{*}$ & 0.171 \\
$\mathrm{UCT}$ & -0.076 & -0.451 \\
Income & 0.104 & -0.002 \\
Education & -0.055 & -0.066 \\
Age & 0.609 & 0.097 \\
Female & 0.128 & 0.152 \\
Children & 0.185 & -0.351 \\
Religiosity & -0.100 & $-0.702 * * *$ \\
Locality Variables & & \\
Population & 0.350 & -0.142 \\
Poverty & -2.070 & -1.953 \\
Education & -0.417 & -0.397 \\
\hline $\mathrm{N}$ (individual) & 956 & 958 \\
$\mathrm{~N}$ (locality) & 20 & 20 \\
$\mathrm{~N}$ (municipality) & 3 & 3 \\
\hline$*$ p<.10, **p<.05, ***p<.01 & \\
Notes: Random-intercept multilevel logistic \\
regression models are used in this analysis.
\end{tabular}


Table A10: Multilevel Models of Political Participation (2014 Mexican Survey Data)

(1)

\section{Electoral}

Political

Participation

\begin{tabular}{lll}
\hline Individual Variables & & \\
CCT & $0.233^{*}$ & $0.582^{* * *}$ \\
UCT & 0.231 & 0.046 \\
Income & $0.087^{*}$ & $0.132^{*}$ \\
Education & 0.016 & -0.016 \\
Age & $1.176^{* * *}$ & 0.120 \\
Female & 0.133 & $0.266^{*}$ \\
Children & -0.052 & $0.587^{* * *}$ \\
Religiosity & -0.063 & 0.094 \\
Locality Variables & & \\
Population & 0.059 & -0.111 \\
Poverty & -0.315 & 0.238 \\
Education & -0.126 & -0.126 \\
\hline N (individual) & 722 & 923 \\
$\mathrm{~N}$ (locality) & 20 & 20 \\
$\mathrm{~N}$ (municipality) & 3 & 3 \\
\hline
\end{tabular}

$* \mathrm{p}<.10, * * \mathrm{p}<.05, * * * \mathrm{p}<.01$

Notes: Random-intercept multilevel linear models are used in this analysis.
(2)

Non-electoral

Political

Participation

$0.582 * * *$

$0.132 *$

$0.266^{*}$

0.094

$-0.111$

-0.238

$-0.126$

3 
Table A11: Multilevel Models of Political Participation (2014 Mexican Survey Data)

(1)

Contact

Public

Officials (alternative measure)
(2)
)

(3)

\begin{tabular}{|c|c|c|c|}
\hline & $\begin{array}{l}\text { Contact } \\
\text { Public } \\
\text { Officials } \\
\text { (alternative } \\
\text { measure) }\end{array}$ & $\begin{array}{l}\text { Community } \\
\text { Activism } \\
\text { (alternative } \\
\text { measure) }\end{array}$ & $\begin{array}{l}\text { Civil } \\
\text { Society } \\
\text { Engage } \\
\text { (alternative } \\
\text { measure) }\end{array}$ \\
\hline \multicolumn{4}{|c|}{ Individual Variables } \\
\hline CCT & $0.173 * *$ & $0.071 * *$ & 0.048 \\
\hline UCT & 0.072 & -0.026 & -0.024 \\
\hline Income & 0.033 & 0.010 & -0.006 \\
\hline Education & -0.028 & 0.001 & 0.003 \\
\hline Age & 0.040 & 0.024 & 0.050 \\
\hline Female & 0.035 & -0.005 & -0.026 \\
\hline Children & $0.161 * *$ & 0.044 & $0.074 * *$ \\
\hline Religiosity & -0.015 & 0.019 & $0.137 * * *$ \\
\hline \multicolumn{4}{|l|}{ Locality Variables } \\
\hline Population & 0.042 & -0.040 & -0.047 \\
\hline Poverty & $-0.369 * *$ & 0.257 & 0.024 \\
\hline Education & -0.078 & 0.022 & -0.005 \\
\hline $\mathrm{N}$ (individual) & 953 & 951 & 952 \\
\hline $\mathrm{N}$ (locality) & 20 & 20 & 20 \\
\hline $\mathrm{N}$ (municipality) & 3 & 3 & 3 \\
\hline
\end{tabular}

$* \mathrm{p}<.10, * * \mathrm{p}<.05, * * * \mathrm{p}<.01$

Notes: Some political activities are not included in the political participation indices in order to create alternative measures of the dependent variables. Random-intercept multilevel linear models are used in this analysis. 
Table A12:Tests of Variance Between Higher-Level Units (2014 Mexican Survey Data)

\begin{tabular}{lcc}
\hline & $\begin{array}{c}\text { Likelihood- } \\
\text { Ratio Test } \\
\text { Statistic }\end{array}$ & P-value \\
\hline Voting & 14.37 & 0.001 \\
Campaign Activism & 12.72 & 0.002 \\
Contact Public Officials & 31.47 & 0.000 \\
Community Activism & 40.79 & 0.000 \\
Civil Society Engage & 36.82 & 0.000 \\
Protest & 15.91 & 0.000 \\
\hline
\end{tabular}

Notes: Likelihood-ratio tests are used for the hypothesis tests in this analysis. The tests analyze variance at the locality and municipality levels. 
Table A13: Linear Regression Models of Political Participation (2014 Mexican Survey Data)

\begin{tabular}{|c|c|c|c|c|c|c|}
\hline & (1) & (2) & (3) & (4) & (5) & (6) \\
\hline & Voting & $\begin{array}{l}\text { Campaign } \\
\text { Activism }\end{array}$ & $\begin{array}{l}\text { Contact } \\
\text { Public } \\
\text { Officials }\end{array}$ & $\begin{array}{l}\text { Community } \\
\text { Activism }\end{array}$ & $\begin{array}{l}\text { Civil } \\
\text { Society } \\
\text { Engage }\end{array}$ & Protest \\
\hline \multicolumn{7}{|c|}{ Individual Variables } \\
\hline CCT & 0.122 & 0.006 & $0.263^{*}$ & $0.139 * * *$ & $0.195 * *$ & $0.052 * *$ \\
\hline UCT & $0.340 * * *$ & -0.010 & 0.155 & -0.018 & 0.005 & -0.020 \\
\hline Income & $0.070 * * *$ & $0.067 * * *$ & 0.056 & 0.020 & -0.002 & 0.002 \\
\hline Education & 0.012 & 0.009 & -0.023 & -0.002 & 0.008 & -0.004 \\
\hline Age & $1.043 * * *$ & $0.122 * *$ & 0.066 & 0.053 & -0.014 & 0.041 \\
\hline Female & 0.069 & -0.002 & $0.155^{* *}$ & -0.016 & $0.095 * * *$ & 0.016 \\
\hline Children & 0.011 & 0.033 & 0.156 & $0.108 * *$ & $0.236 * * *$ & -0.019 \\
\hline Religiosity & -0.020 & -0.002 & -0.067 & 0.017 & $0.169 * * *$ & -0.046 \\
\hline $\mathrm{N}$ (individual) & 916 & 947 & 949 & 944 & 946 & 956 \\
\hline \multicolumn{7}{|c|}{$* \mathrm{p}<.10, * * \mathrm{p}<.05, * * * \mathrm{p}<.01$} \\
\hline \multicolumn{7}{|c|}{$\begin{array}{l}\text { Notes: Ordinary least squares linear regression models with clustered standard errors are } \\
\text { used in this analysis. Dummy variables for municipalities and localities are included in } \\
\text { the models. }\end{array}$} \\
\hline
\end{tabular}


Table A14: Multilevel Models of Political Participation (2014 Mexican Survey Data)

\begin{tabular}{|c|c|c|c|c|c|c|}
\hline & (1) & (2) & (3) & (4) & (5) & (6) \\
\hline & Voting & $\begin{array}{l}\text { Campaign } \\
\text { Activism }\end{array}$ & $\begin{array}{l}\text { Contact } \\
\text { Public } \\
\text { Officials }\end{array}$ & $\begin{array}{l}\text { Community } \\
\text { Activism }\end{array}$ & $\begin{array}{l}\text { Civil } \\
\text { Society } \\
\text { Engage }\end{array}$ & Protest \\
\hline \multicolumn{7}{|c|}{ Individual Variables } \\
\hline CCT & $0.153^{*}$ & -0.013 & $0.268 * * *$ & $0.126^{* * * *}$ & $0.176 * * *$ & 0.037 \\
\hline UCT & $0.304 * *$ & -0.004 & 0.107 & -0.005 & 0.028 & -0.019 \\
\hline Wealth Index & $0.034 * *$ & $0.013 * *$ & 0.001 & 0.007 & 0.007 & 0.003 \\
\hline Education & 0.011 & $0.017^{*}$ & -0.011 & -0.007 & 0.005 & -0.009 \\
\hline Age & $1.044 * * *$ & $0.110 * *$ & 0.088 & 0.011 & -0.044 & 0.021 \\
\hline Female & 0.028 & -0.012 & 0.085 & -0.010 & $0.087 * *$ & 0.005 \\
\hline Children & 0.076 & 0.046 & $0.198 *$ & $0.126 * * *$ & $0.230 * * *$ & -0.024 \\
\hline Religiosity & -0.014 & 0.003 & -0.057 & 0.016 & $0.178 * * *$ & $-0.038 * * *$ \\
\hline \multicolumn{7}{|l|}{ Locality Variables } \\
\hline Population & 0.018 & 0.028 & -0.042 & -0.054 & -0.014 & 0.002 \\
\hline Poverty & $-0.522 * * *$ & 0.127 & -0.179 & $0.462 * *$ & 0.017 & -0.078 \\
\hline Education & -0.080 & -0.050 & -0.054 & 0.042 & -0.057 & -0.032 \\
\hline $\mathrm{N}$ (individual) & 1010 & 1043 & 1047 & 1042 & 1043 & 1054 \\
\hline $\mathrm{N}$ (locality) & 20 & 20 & 20 & 20 & 20 & 20 \\
\hline $\mathrm{N}$ (municipality) & 3 & 3 & 3 & 3 & 3 & 3 \\
\hline
\end{tabular}


Table A15: Multilevel Models of Political Participation (2014 Mexican Survey Data)

\begin{tabular}{|c|c|c|c|c|c|c|}
\hline & (1) & (2) & (3) & (4) & (5) & (6) \\
\hline & Voting & $\begin{array}{l}\text { Campaign } \\
\text { Activism }\end{array}$ & $\begin{array}{l}\text { Contact } \\
\text { Public } \\
\text { Officials }\end{array}$ & $\begin{array}{l}\text { Community } \\
\text { Activism }\end{array}$ & $\begin{array}{l}\text { Civil } \\
\text { Society } \\
\text { Engage }\end{array}$ & Protest \\
\hline \multicolumn{7}{|c|}{ Individual Variables } \\
\hline $\mathrm{CCT}$ & $0.245 * * *$ & 0.032 & $0.333 * * *$ & $0.101 * *$ & $0.129 * * *$ & $0.110 * * *$ \\
\hline UCT & $0.356^{* * *}$ & 0.010 & 0.226 & -0.008 & -0.004 & 0.016 \\
\hline Income & $0.061 *$ & $0.067 * * *$ & 0.062 & 0.022 & 0.000 & 0.003 \\
\hline Education & 0.024 & 0.007 & -0.021 & -0.004 & 0.004 & -0.003 \\
\hline Age & $1.096 * * *$ & $0.109 * *$ & 0.089 & 0.050 & -0.021 & 0.042 \\
\hline Female & 0.051 & -0.003 & 0.130 & -0.016 & $0.090 * *$ & 0.013 \\
\hline Children & 0.060 & 0.028 & $0.203 *$ & $0.117 * *$ & $0.267 * * *$ & -0.025 \\
\hline Religiosity & -0.016 & -0.002 & -0.061 & 0.017 & $0.171 * * *$ & $-0.046 * * *$ \\
\hline \multicolumn{7}{|l|}{ Locality Variables } \\
\hline Population & 0.006 & 0.035 & -0.057 & -0.064 & -0.021 & -0.002 \\
\hline Poverty & $-0.548 * * *$ & 0.130 & -0.219 & $0.451 *$ & 0.026 & -0.082 \\
\hline Education & -0.059 & -0.054 & -0.051 & 0.051 & -0.049 & -0.027 \\
\hline N (individual) & 916 & 947 & 949 & 944 & 946 & 956 \\
\hline N (locality) & 20 & 20 & 20 & 20 & 20 & 20 \\
\hline $\mathrm{N}$ (municipality) & 3 & 3 & 3 & 3 & 3 & 3 \\
\hline
\end{tabular}

$* \mathrm{p}<.10, * * \mathrm{p}<.05, * * * \mathrm{p}<.01$

Notes: The CCT participation variable includes current and former CCT beneficiaries. Randomintercept multilevel linear models are used in this analysis. 
Table A16: Linear Regression Models of Political Participation (2014 Mexican Survey Data)

\begin{tabular}{|c|c|c|c|c|c|c|}
\hline & (1) & (2) & (3) & (4) & $(5)$ & (6) \\
\hline & Voting & $\begin{array}{l}\text { Campaign } \\
\text { Activism }\end{array}$ & $\begin{array}{l}\text { Contact } \\
\text { Public } \\
\text { Officials }\end{array}$ & $\begin{array}{l}\text { Community } \\
\text { Activism }\end{array}$ & $\begin{array}{l}\text { Civil } \\
\text { Society } \\
\text { Engage }\end{array}$ & Protest \\
\hline \multicolumn{7}{|c|}{ Individual Variables } \\
\hline $\mathrm{CCT}$ & 0.160 & 0.003 & $0.454 * *$ & $0.136 * *$ & $0.242 * *$ & $0.071 * *$ \\
\hline Male & -0.046 & 0.000 & -0.039 & 0.014 & $-0.067 *$ & -0.004 \\
\hline $\mathrm{CCT}^{*}$ Male & -0.080 & 0.006 & $-0.396^{*}$ & 0.006 & -0.097 & -0.040 \\
\hline UCT & $0.341 * * *$ & -0.010 & 0.160 & -0.019 & 0.007 & -0.020 \\
\hline Income & $0.069 * * *$ & $0.067 * * *$ & 0.053 & 0.020 & -0.003 & 0.001 \\
\hline Education & 0.012 & 0.009 & -0.021 & -0.002 & 0.008 & -0.004 \\
\hline Age & $1.044 * * *$ & $0.122 * *$ & 0.067 & 0.053 & -0.013 & 0.041 \\
\hline Children & 0.012 & 0.033 & 0.162 & $0.108 * *$ & $0.237 * * *$ & -0.019 \\
\hline Religiosity & -0.018 & -0.002 & -0.062 & 0.017 & $0.171 * * *$ & -0.045 \\
\hline $\mathrm{N}$ (individual) & 916 & 947 & 949 & 944 & 946 & 956 \\
\hline \multicolumn{7}{|c|}{$* \mathrm{p}<.10, * * \mathrm{p}<.05, * * * \mathrm{p}<.01$} \\
\hline \multicolumn{7}{|c|}{$\begin{array}{l}\text { Notes: Ordinary least squares linear regression models with clustered standard errors are } \\
\text { used in this analysis. Dummy variables for municipalities and localities are included in the } \\
\text { models. }\end{array}$} \\
\hline
\end{tabular}


Table A17: Multilevel Models of Political Participation (2014 Mexican Survey Data)

\begin{tabular}{|c|c|c|c|c|c|c|}
\hline & (1) & (2) & (3) & (4) & (5) & (6) \\
\hline & Voting & $\begin{array}{l}\text { Campaign } \\
\text { Activism }\end{array}$ & $\begin{array}{l}\text { Contact } \\
\text { Public } \\
\text { Officials }\end{array}$ & $\begin{array}{l}\text { Community } \\
\text { Activism }\end{array}$ & $\begin{array}{l}\text { Civil } \\
\text { Society } \\
\text { Engage }\end{array}$ & Protest \\
\hline \multicolumn{7}{|c|}{ Individual Variables } \\
\hline $\mathrm{CCT}$ & 0.133 & 0.003 & 0.075 & $0.134 * *$ & $0.145^{* *}$ & 0.027 \\
\hline Female & 0.019 & 0.001 & 0.019 & -0.016 & 0.065 & 0.004 \\
\hline CCT*Female & 0.105 & -0.015 & $0.369^{*}$ & -0.002 & 0.081 & 0.030 \\
\hline UCT & $0.304 * *$ & -0.008 & 0.158 & -0.012 & -0.002 & -0.024 \\
\hline Income & $0.063^{*}$ & $0.068 * * *$ & 0.061 & 0.022 & -0.000 & 0.004 \\
\hline Education & 0.021 & 0.005 & -0.024 & -0.003 & 0.006 & -0.006 \\
\hline Age & $1.082 * * *$ & $0.104 * *$ & 0.070 & 0.048 & -0.021 & 0.031 \\
\hline Children & 0.063 & 0.033 & $0.210 *$ & $0.109^{* *}$ & $0.255^{* * *}$ & -0.016 \\
\hline Religiosity & -0.015 & -0.002 & -0.056 & 0.016 & $0.170 * * *$ & $-0.045 * * *$ \\
\hline \multicolumn{7}{|c|}{ Locality Variables } \\
\hline Population & 0.011 & 0.034 & -0.048 & -0.056 & -0.012 & -0.000 \\
\hline Poverty & $-0.534 * * *$ & 0.138 & -0.237 & $0.444 *$ & 0.005 & -0.075 \\
\hline Education & -0.067 & -0.055 & -0.060 & 0.048 & -0.053 & -0.031 \\
\hline $\mathrm{N}$ (individual) & 916 & 947 & 949 & 944 & 946 & 956 \\
\hline N (locality) & 20 & 20 & 20 & 20 & 20 & 20 \\
\hline $\mathrm{N}$ (municipality) & 3 & 3 & 3 & 3 & 3 & 3 \\
\hline
\end{tabular}


Table A18: Multilevel Models of Civic Skills (2014 Mexican Survey Data)

\begin{tabular}{llll}
\hline & $(1)$ & $(2)$ & $(3)$ \\
& $\begin{array}{l}\text { Organized a } \\
\text { Meeting or } \\
\text { Set Up an } \\
\text { Appointment }\end{array}$ & $\begin{array}{l}\text { Asked } \\
\text { Someone to } \\
\text { Clarify } \\
\text { Information }\end{array}$ & $\begin{array}{l}\text { Civic Skills } \\
\text { Index } \\
\text { (alternative } \\
\text { measure) }\end{array}$ \\
\hline Individual Variables & & & \\
CCT & $0.115^{* * *}$ & $0.140^{* * *}$ & $0.042^{* * *}$ \\
UCT & 0.086 & 0.021 & 0.019 \\
Income & $0.045^{* * *}$ & $0.053^{* * *}$ & $0.016^{* * *}$ \\
Education & 0.004 & 0.007 & 0.002 \\
Age & -0.007 & -0.019 & -0.001 \\
Female & $0.087 * *$ & -0.017 & 0.012 \\
Children & 0.026 & -0.009 & 0.001 \\
Religiosity & -0.010 & 0.007 & -0.001 \\
Locality Variables & & & \\
Population & -0.014 & 0.034 & 0.000 \\
Poverty & 0.196 & 0.049 & 0.048 \\
Education & -0.003 & -0.024 & -0.005 \\
\hline N (individual) & 949 & 947 & 942 \\
N (locality) & 20 & 20 & 20 \\
N (municipality) & 3 & 3 & 3 \\
\hline$*$ p<10 **p<.05,**p<.01 & &
\end{tabular}

Notes: Some civic skills are not included in the civic skills index in order to create an alternative measure of this dependent variable. Random-intercept multilevel linear models are used in this analysis. 
Table A19: Tests of Variance Between Higher-Level Units (2014 Mexican Survey Data)

\begin{tabular}{lcc} 
& $\begin{array}{c}\text { Likelihood- } \\
\text { Ratio Test } \\
\text { Statistic }\end{array}$ & P-value \\
\hline $\begin{array}{l}\text { Attended a Meeting and } \\
\text { Participated in the } \\
\text { Discussion }\end{array}$ & 9.28 & 0.010 \\
$\begin{array}{l}\text { Organized a Meeting or } \\
\text { Set Up an Appointment }\end{array}$ & 16.92 & 0.000 \\
$\begin{array}{l}\text { Wrote a Letter or Filled } \\
\text { Out Forms } \\
\begin{array}{l}\text { Asked Someone to } \\
\text { Clarify Information } \\
\text { Civic Skills Index }\end{array}\end{array}$ & 26.37 & 0.000 \\
\hline
\end{tabular}

Notes: Likelihood-ratio tests are used for the hypothesis tests in this analysis. The tests analyze variance at the locality and municipality levels. 
Table A20: Linear Regression Models of Civic Skills (2014 Mexican Survey Data)

(1)

Asked Someone to

Clarify Information

\section{Individual Variables}

CCT

$0.145 * * *$

UCT

0.030

Income

$0.051 * * *$

Education

0.005

Age

$-0.029$

Female

$-0.015$

Children

$-0.013$

Religiosity

0.008

$\mathrm{N}$ (individual)

947

$* \mathrm{p}<.10, * * \mathrm{p}<.05, * * * \mathrm{p}<.01$

Notes: Ordinary least squares linear regression models are used in this analysis. No dummy variables are included in the models. 
Table A21: Linear Regression Models of Civic Skills (2014 Mexican Survey Data)

\begin{tabular}{|c|c|c|c|c|c|}
\hline & (1) & (2) & (3) & (4) & (5) \\
\hline & $\begin{array}{l}\text { Attended a } \\
\text { Meeting and } \\
\text { Participated } \\
\text { in the } \\
\text { Discussion } \\
\end{array}$ & $\begin{array}{l}\text { Organized a } \\
\text { Meeting or } \\
\text { Set Up an } \\
\text { Appointment }\end{array}$ & $\begin{array}{l}\text { Wrote a } \\
\text { Letter or } \\
\text { Filled } \\
\text { Out } \\
\text { Forms } \\
\end{array}$ & $\begin{array}{l}\text { Asked } \\
\text { Someone to } \\
\text { Clarify } \\
\text { Information }\end{array}$ & $\begin{array}{l}\text { Civic } \\
\text { Skills } \\
\text { Index }\end{array}$ \\
\hline \multicolumn{6}{|c|}{ Individual Variables } \\
\hline $\mathrm{CCT}$ & $0.357 * * *$ & $0.116^{* *}$ & $0.138 * * *$ & $0.138 * * *$ & $0.251 * * *$ \\
\hline UCT & $0.213 * *$ & 0.085 & 0.002 & 0.028 & $0.122 *$ \\
\hline Income & 0.019 & $0.041 *$ & $0.034 * * *$ & $0.053 * * *$ & $0.046 * *$ \\
\hline Education & -0.002 & 0.005 & -0.000 & 0.009 & 0.003 \\
\hline Age & 0.051 & -0.006 & -0.015 & -0.002 & 0.008 \\
\hline Female & $0.098 *$ & $0.088 *$ & -0.004 & -0.015 & 0.043 \\
\hline Children & 0.007 & 0.017 & 0.034 & -0.019 & 0.011 \\
\hline Religiosity & $0.045 * * *$ & -0.010 & -0.001 & 0.006 & 0.013 \\
\hline $\mathrm{N}$ (individual) & 949 & 949 & 947 & 947 & 936 \\
\hline \multicolumn{6}{|c|}{$* \mathrm{p}<.10, * * \mathrm{p}<.05, * * * \mathrm{p}<.01$} \\
\hline \multicolumn{6}{|c|}{$\begin{array}{l}\text { Notes: Ordinary least squares linear regression models with clustered standard errors are } \\
\text { used in this analysis. Dummy variables for municipalities and localities are included in the } \\
\text { models. }\end{array}$} \\
\hline
\end{tabular}


Table A22: Linear Regression Models of Civic Skills (2014 Mexican Survey Data)

\begin{tabular}{llllll}
\hline & $\begin{array}{l}\text { (1) } \\
\text { Attended a } \\
\text { Meeting and } \\
\text { Participated } \\
\text { in the } \\
\text { Discussion }\end{array}$ & $\begin{array}{l}\text { Organized a } \\
\text { Meeting or } \\
\text { Set Up an } \\
\text { Appointment }\end{array}$ & $\begin{array}{l}\text { Wrote a } \\
\text { Letter or } \\
\text { Filled Out } \\
\text { Forms }\end{array}$ & $\begin{array}{l}\text { Asked } \\
\text { Someone to } \\
\text { Clarify } \\
\text { Information }\end{array}$ & $\begin{array}{l}\text { Civic } \\
\text { Skills } \\
\text { Index }\end{array}$ \\
\hline $\begin{array}{l}\text { Individual Variables } \\
\text { CCT }\end{array}$ & $0.532^{* * *}$ & $0.184^{* * *}$ & $0.221^{* * *}$ & $0.188^{* * *}$ & $0.377^{* * *}$ \\
Male & 0.005 & -0.047 & 0.054 & 0.045 & 0.031 \\
CCT*Male & $-0.359^{* * *}$ & $-0.141^{*}$ & -0.170 & -0.104 & $-0.256^{* *}$ \\
UCT & $0.218^{* *}$ & 0.087 & 0.005 & 0.029 & $0.126^{*}$ \\
Income & 0.016 & $0.041^{*}$ & $0.033^{* * *}$ & $0.052^{* * *}$ & $0.044^{* *}$ \\
Education & -0.000 & 0.006 & 0.001 & 0.010 & 0.005 \\
Age & 0.053 & -0.005 & -0.015 & -0.002 & 0.008 \\
Children & 0.011 & 0.018 & 0.036 & -0.018 & 0.014 \\
Religiosity & $0.050^{* * *}$ & -0.008 & 0.001 & 0.008 & 0.017 \\
\hline N (individual) & 949 & 949 & 947 & 947 & 936 \\
\hline$*$ p $<.10, * * \mathrm{p}<.05, * * * p<.01$ & & & \\
Notes: Ordinary least squares linear regression models with clustered standard errors are \\
used in this analysis. Dummy variables for municipalities and localities are included in the \\
models.
\end{tabular}


Table A23: Multilevel Models of Civic Skills (2014 Mexican Survey Data)

\begin{tabular}{llllll}
\hline & $(1)$ & $(2)$ & $(3)$ & $(4)$ & $(5)$ \\
& $\begin{array}{l}\text { Attended a } \\
\text { Meeting and } \\
\text { Participated } \\
\text { in the } \\
\text { Discussion }\end{array}$ & $\begin{array}{l}\text { Organized a } \\
\text { Meeting or } \\
\text { Set Up an } \\
\text { Appointment }\end{array}$ & $\begin{array}{l}\text { Wrote a } \\
\text { Letter or } \\
\text { Filled } \\
\text { Out }\end{array}$ & $\begin{array}{l}\text { Forms } \\
\text { Asked } \\
\text { Someone to } \\
\text { Clarify } \\
\text { Information }\end{array}$ & $\begin{array}{l}\text { Civic } \\
\text { Skills } \\
\text { Index }\end{array}$ \\
\hline Individual Variables & & & & & \\
CCT & $0.158^{* *}$ & 0.038 & 0.043 & 0.082 & $0.106^{*}$ \\
Female & 0.010 & 0.043 & -0.061 & -0.050 & -0.035 \\
CCT*Female & $0.363^{* * *}$ & $0.148^{*}$ & $0.180^{* *}$ & 0.111 & $0.271^{* * *}$ \\
UCT & $0.224^{* * *}$ & 0.088 & 0.013 & 0.024 & $0.124^{* *}$ \\
Income & 0.014 & $0.044^{* * *}$ & $0.039^{* *}$ & $0.052^{* * *}$ & $0.050^{* * *}$ \\
Education & -0.001 & 0.004 & -0.002 & 0.007 & 0.000 \\
Age & 0.031 & -0.007 & -0.018 & -0.020 & -0.008 \\
Children & -0.020 & 0.029 & 0.049 & -0.008 & 0.025 \\
Religiosity & $0.048^{*}$ & -0.008 & 0.002 & 0.009 & 0.019 \\
Locality Variables & & & & & \\
Population & 0.041 & -0.014 & 0.011 & 0.033 & 0.031 \\
Poverty & $0.300^{* * *}$ & 0.180 & 0.041 & 0.041 & $0.155^{* *}$ \\
Education & -0.020 & -0.002 & -0.037 & -0.023 & -0.020 \\
\hline N (individual) & 949 & 949 & 947 & 947 & 936 \\
N (locality) & 20 & 20 & 20 & 20 & 20 \\
N (municipality) & 3 & 3 & 3 & 3 & 3 \\
\hline$*$ p<.10, **p $<.05, * * * p<.01$ & & & & \\
Notes: Random-intercept multilevel linear models are used in this analysis. & \\
\hline & & & & & \\
\hline
\end{tabular}


Table A24: Multilevel Models of Political Attitudes (2014 Mexican Survey Data)

\begin{tabular}{|c|c|c|c|c|c|c|}
\hline & (1) & (2) & (3) & (4) & $(5)$ & (6) \\
\hline & $\begin{array}{l}\text { Govt } \\
\text { Interested } \\
\text { in You } \\
\text { (external } \\
\text { political } \\
\text { efficacy) } \\
\end{array}$ & $\begin{array}{l}\text { Vote } \\
\text { Matters } \\
\text { (external } \\
\text { political } \\
\text { efficacy) } \\
\end{array}$ & $\begin{array}{l}\text { Understand } \\
\text { Political } \\
\text { Issues } \\
\text { (internal } \\
\text { political } \\
\text { efficacy) }\end{array}$ & $\begin{array}{l}\text { Informed } \\
\text { about Loc } \\
\text { Govt } \\
\text { (internal } \\
\text { political } \\
\text { efficacy) } \\
\end{array}$ & $\begin{array}{l}\text { Ability to } \\
\text { Help Com } \\
\text { Group } \\
\text { (internal } \\
\text { political } \\
\text { efficacy) } \\
\end{array}$ & $\begin{array}{l}\text { Interest } \\
\text { in } \\
\text { Politics }\end{array}$ \\
\hline \multicolumn{7}{|c|}{ Individual Variables } \\
\hline CCT & 0.079 & 0.045 & -0.032 & 0.029 & 0.016 & 0.031 \\
\hline UCT & 0.012 & -0.180 & -0.024 & 0.027 & 0.008 & 0.021 \\
\hline Income & -0.042 & 0.000 & 0.001 & -0.005 & 0.040 & -0.015 \\
\hline Education & $-0.048 *$ & 0.007 & 0.008 & 0.035 & $0.064 * * *$ & $0.044 * *$ \\
\hline Age & -0.025 & -0.050 & 0.130 & 0.127 & $0.253 * *$ & 0.131 \\
\hline Female & -0.096 & 0.033 & $-0.199 * * *$ & $-0.163 * *$ & -0.089 & $-0.225 * * *$ \\
\hline Children & $0.195 * *$ & -0.025 & $0.260 * * *$ & $0.273 * * *$ & $-0.138 *$ & -0.023 \\
\hline Religiosity & 0.011 & -0.061 & 0.040 & 0.052 & -0.024 & $0.074 * * *$ \\
\hline \multicolumn{7}{|l|}{ Locality Variables } \\
\hline Population & 0.024 & 0.015 & -0.067 & -0.068 & $0.151 * *$ & -0.049 \\
\hline Poverty & -0.191 & 0.117 & 0.125 & $0.302 * *$ & -0.065 & 0.047 \\
\hline Education & -0.079 & -0.053 & $0.122 * *$ & 0.092 & $-0.161 * * *$ & 0.017 \\
\hline N (individual) & 939 & 938 & 933 & 931 & 944 & 954 \\
\hline N (locality) & 20 & 20 & 20 & 20 & 20 & 20 \\
\hline $\mathrm{N}$ (municipality) & 3 & 3 & 3 & 3 & 3 & 3 \\
\hline
\end{tabular}


Table A25: Confirmatory Factor Analysis Results for the Political Participation Indices (2012 LAPOP Survey Data)

\begin{tabular}{|c|c|c|c|c|c|}
\hline & Voting & $\begin{array}{l}\text { Campaign } \\
\text { Activism }\end{array}$ & $\begin{array}{l}\text { Contacting } \\
\text { Public } \\
\text { Officials }\end{array}$ & $\begin{array}{l}\text { Community } \\
\text { Activism }\end{array}$ & $\begin{array}{l}\text { Civil Society } \\
\text { Engagement }\end{array}$ \\
\hline RMSEA & .00 & .00 & .03 & .01 & .07 \\
\hline CFI & 1.00 & 1.00 & .90 & 1.00 & .70 \\
\hline $\mathrm{N}$ & 11,446 & 13,232 & 13,424 & 13,287 & 13,428 \\
\hline
\end{tabular}

Notes: The two variables in the protest index (participation in a protest and participation in a blockade) are not able to be assessed using confirmatory factor analysis, because all respondents who participated in a blockade also participated in a protest. 
Table A26: Multilevel Models of Voting (2012 LAPOP Survey Data)

\begin{tabular}{|c|c|c|c|}
\hline & $\begin{array}{l}\text { Registered } \\
\text { to Vote }\end{array}$ & $\begin{array}{l}(2) \\
\text { Voted in } \\
\text { Last } \\
\text { Presidential } \\
\text { Election }\end{array}$ & $\begin{array}{l}(3) \\
\text { Would } \\
\text { Vote in } \\
\text { Current } \\
\text { Presidential } \\
\text { Election }\end{array}$ \\
\hline CCT & -0.073 & 0.084 & $0.205 * *$ \\
\hline UCT & 0.200 & 0.003 & 0.269 \\
\hline Income & $0.038 * *$ & 0.011 & 0.017 \\
\hline Education & $0.069 * * *$ & $0.066 * * *$ & $0.040 * * *$ \\
\hline Age & $2.044 * * *$ & $2.329 * * *$ & $0.429 * * *$ \\
\hline Female & -0.027 & 0.032 & -0.024 \\
\hline Children & -0.012 & $0.326 * * *$ & 0.089 \\
\hline Religiosity & 0.041 & $0.085 * * *$ & $0.143 * * *$ \\
\hline Population & $-0.344 * *$ & $-0.158 *$ & -0.012 \\
\hline $\mathrm{N}$ (individual) & 7832 & 7830 & 6781 \\
\hline N (municipality) & 637 & 637 & 636 \\
\hline $\mathrm{N}$ (country) & 9 & 9 & 9 \\
\hline \multicolumn{4}{|c|}{$* \mathrm{p}<.10, * * \mathrm{p}<.05, * * * \mathrm{p}<.01$} \\
\hline \multicolumn{4}{|c|}{$\begin{array}{l}\text { Notes: Random-intercept multilevel logistic regression models } \\
\text { are used in this analysis. }\end{array}$} \\
\hline
\end{tabular}


Table A27: Multilevel Models of Campaign Activism (2012 LAPOP Survey Data)

\begin{tabular}{|c|c|c|c|}
\hline & \multirow[b]{2}{*}{$\begin{array}{l}1) \\
\text { Tried to } \\
\text { Convince } \\
\text { Others to } \\
\text { Vote }\end{array}$} & \multirow[b]{2}{*}{$\begin{array}{l}(2) \\
\text { Participated } \\
\text { in Electoral } \\
\text { Campaign } \\
\text { in Last } \\
\text { Election }\end{array}$} & \multirow{2}{*}{$\begin{array}{l}\text { (3) } \\
\text { Attended } \\
\text { Meetings for a } \\
\text { Political Party }\end{array}$} \\
\hline & & & \\
\hline CCT & $0.112 * * *$ & $0.661 * * *$ & $0.083 * * *$ \\
\hline UCT & 0.126 & -1.304 & -0.025 \\
\hline Income & 0.002 & 0.016 & -0.001 \\
\hline Education & $0.022 * * *$ & $0.057 * * *$ & $0.008 * * *$ \\
\hline Age & $0.159^{* * *}$ & $0.396^{* * *}$ & $0.056 * * *$ \\
\hline Female & $-0.142 * * *$ & $-0.374 * * *$ & $-0.089 * * *$ \\
\hline Children & $0.048^{*}$ & 0.175 & 0.012 \\
\hline Religiosity & $0.015^{*}$ & $0.084 * * *$ & $0.018 * * *$ \\
\hline Population & 0.034 & $-0.180 *$ & $-0.031 *$ \\
\hline $\mathrm{N}$ (individual) & 7793 & 7797 & 7811 \\
\hline $\mathrm{N}$ (municipality) & 637 & 637 & 637 \\
\hline $\mathrm{N}$ (country) & 9 & 9 & 9 \\
\hline \multicolumn{4}{|c|}{$\begin{array}{l}* \mathrm{p}<.10, * * \mathrm{p}<.05, * * * \mathrm{p}<.01 \\
\text { Notes: Random-intercept multilevel logistic regression models and } \\
\text { random-intercept multilevel linear regression models are used in this } \\
\text { analysis. }\end{array}$} \\
\hline
\end{tabular}


Table A28: Multilevel Models of Contacting Public Officials (2012 LAPOP Survey Data)

\begin{tabular}{|c|c|c|c|c|c|}
\hline & (1) & (2) & (3) & (4) & (5) \\
\hline & $\begin{array}{l}\text { Contacted } \\
\text { Member of } \\
\text { the } \\
\text { Legislature }\end{array}$ & $\begin{array}{l}\text { Contacted } \\
\text { Local } \\
\text { Politician } \\
\end{array}$ & $\begin{array}{l}\text { Contacted } \\
\text { State } \\
\text { Official }\end{array}$ & $\begin{array}{l}\text { Presented } \\
\text { Petition }\end{array}$ & $\begin{array}{l}\text { Signed } \\
\text { Petition }\end{array}$ \\
\hline $\mathrm{CCT}$ & 0.119 & $0.314 * * *$ & $0.358 * * *$ & $0.388 * * *$ & $0.429 * * *$ \\
\hline UCT & 0.612 & -0.076 & -0.177 & -0.330 & -1.217 \\
\hline Income & 0.004 & $-0.047 * * *$ & -0.022 & $-0.035 * * *$ & $0.036 * * *$ \\
\hline Education & $0.031 * *$ & $0.025 * *$ & $0.049 * * *$ & $0.046 * * *$ & $0.091 * * *$ \\
\hline Age & $0.520 * * *$ & $0.441 * * *$ & $0.223 *$ & $0.322 * * *$ & $0.267 * *$ \\
\hline Female & -0.127 & $-0.137 *$ & $-0.147^{*}$ & -0.038 & $-0.196 * *$ \\
\hline Children & $0.302 * *$ & $0.268 * * *$ & $0.367 * * *$ & $0.311 * * *$ & 0.021 \\
\hline Religiosity & $0.127 * * *$ & $0.141 * * *$ & $0.076 * *$ & $0.074 * * *$ & $0.103 * * *$ \\
\hline Population & $-0.285^{* *}$ & $-0.407 * * *$ & 0.032 & $-0.167 *$ & -0.065 \\
\hline $\mathrm{N}$ (individual) & 7841 & 7845 & 7839 & 7831 & 7802 \\
\hline N (municipality) & 637 & 637 & 637 & 637 & 637 \\
\hline $\mathrm{N}$ (country) & 9 & 9 & 9 & 9 & 9 \\
\hline $\begin{array}{l}* \mathrm{p}<.10, * * \mathrm{p}<.05, \\
\text { Notes: Random-in } \\
\text { analysis. }\end{array}$ & $* * p<.01$ & 11 & 年 & the & this \\
\hline
\end{tabular}


Table A29: Multilevel Models of Community Activism (2012 LAPOP Survey Data)

\begin{tabular}{|c|c|c|c|c|}
\hline & (1) & (2) & (3) & (4) \\
\hline & $\begin{array}{l}\text { Attended } \\
\text { Municipal } \\
\text { Session }\end{array}$ & $\begin{array}{l}\text { Helped } \\
\text { Resolve a } \\
\text { Community } \\
\text { Problem }\end{array}$ & $\begin{array}{l}\text { Attended } \\
\text { Meetings for } \\
\text { a Community } \\
\text { Improvement } \\
\text { Group }\end{array}$ & $\begin{array}{l}\text { Organized } \\
\text { with } \\
\text { Neighbors } \\
\text { Against } \\
\text { Crime }\end{array}$ \\
\hline $\mathrm{CCT}$ & $0.272 * * *$ & -0.015 & $0.067 * * *$ & -0.020 \\
\hline UCT & 0.104 & -0.081 & -0.109 & $-0.905^{*}$ \\
\hline Income & -0.016 & 0.003 & -0.001 & $-0.020 * *$ \\
\hline Education & $0.051 * * *$ & $0.024 * * *$ & $0.010 * * *$ & $0.028 * * *$ \\
\hline Age & $0.419 * * *$ & $0.204 * * *$ & $0.189 * * *$ & $0.264 * * *$ \\
\hline Female & $-0.331 * * *$ & $-0.107 * * *$ & $-0.072 * * *$ & $-0.212 * * *$ \\
\hline Children & $0.273^{* *}$ & 0.020 & $0.082 * * *$ & $0.324 * * *$ \\
\hline Religiosity & $0.168 * * *$ & $0.058 * * *$ & $0.037 * * *$ & $0.132 * * *$ \\
\hline Population & $-0.468 * * *$ & $-0.128 * * *$ & $-0.205^{* * *}$ & 0.019 \\
\hline N (individual) & 7809 & 7761 & 7833 & 7841 \\
\hline $\mathrm{N}$ (municipality) & 636 & 637 & 637 & 637 \\
\hline $\mathrm{N}$ (country) & 9 & 9 & 9 & 9 \\
\hline
\end{tabular}

$* \mathrm{p}<.10, * * \mathrm{p}<.05, * * * \mathrm{p}<.01$

Notes: Random-intercept multilevel logistic regression models and randomintercept multilevel linear regression models are used in this analysis. 
Table A30: Multilevel Models of Civil Society Engagement (2012 LAPOP Survey Data)

\begin{tabular}{|c|c|c|c|c|}
\hline & (1) & (2) & (3) & (4) \\
\hline & $\begin{array}{l}\text { Attended } \\
\text { Religious } \\
\text { Organization } \\
\text { Meetings }\end{array}$ & $\begin{array}{l}\text { Attended } \\
\text { School } \\
\text { Organization } \\
\text { Meetings }\end{array}$ & $\begin{array}{l}\text { Attended } \\
\text { Professional } \\
\text { Organization } \\
\text { Meetings }\end{array}$ & $\begin{array}{l}\text { Attended } \\
\text { Sports } \\
\text { Group } \\
\text { Meetings }\end{array}$ \\
\hline CCT & 0.002 & $0.128 * * *$ & $0.049 * * *$ & 0.021 \\
\hline UCT & 0.085 & -0.128 & -0.005 & -0.020 \\
\hline Income & -0.002 & -0.002 & $0.011 * * *$ & $0.009 * * *$ \\
\hline Education & $0.006^{* *}$ & $0.017 * * *$ & $0.018 * * *$ & $0.022 * * *$ \\
\hline Age & $0.104 * * *$ & $-0.323 * * *$ & $0.080 * * *$ & $-0.299 * * *$ \\
\hline Female & $0.069^{* * *}$ & $0.234 * * *$ & $-0.095 * * *$ & $-0.444 * * *$ \\
\hline Children & 0.021 & $0.700 * * *$ & $0.057 * * *$ & $-0.052 * *$ \\
\hline Religiosity & $0.567 * * *$ & $0.055 * * *$ & $0.013 * * *$ & $0.042 * * *$ \\
\hline Population & -0.022 & $-0.116^{* * *}$ & $-0.122 * * *$ & -0.031 \\
\hline $\mathrm{N}$ (individual) & 7845 & 7837 & 7826 & 7792 \\
\hline $\mathrm{N}$ (municipality) & 637 & 637 & 637 & 637 \\
\hline $\mathrm{N}$ (country) & 9 & 9 & 9 & 9 \\
\hline
\end{tabular}

$* \mathrm{p}<.10, * * \mathrm{p}<.05, * * * \mathrm{p}<.01$

Notes: Random-intercept multilevel linear regression models are used in this analysis. 
Table A31: Multilevel Models of Protest (2012 LAPOP Survey Data)

\begin{tabular}{|c|c|c|}
\hline & (1) & (2) \\
\hline & $\begin{array}{l}\text { Participated in } \\
\text { Protest }\end{array}$ & $\begin{array}{l}\text { Participated in } \\
\text { Blockade }\end{array}$ \\
\hline $\mathrm{CCT}$ & $0.383 * * *$ & $0.549 * * *$ \\
\hline UCT & 0.496 & $1.290 *$ \\
\hline Income & 0.009 & -0.020 \\
\hline Education & $0.105 * * *$ & $0.102 * * *$ \\
\hline Age & -0.111 & $-0.700 * * *$ \\
\hline Female & $-0.240 * * *$ & -0.219 \\
\hline Children & -0.144 & -0.133 \\
\hline Religiosity & $0.056 *$ & 0.010 \\
\hline Population & 0.173 & 0.174 \\
\hline $\mathrm{N}$ (individual) & 7826 & 7793 \\
\hline N (municipality) & 637 & 637 \\
\hline $\mathrm{N}$ (country) & 9 & 9 \\
\hline \multicolumn{3}{|c|}{$* \mathrm{p}<.10, * * \mathrm{p}<.05, * * * \mathrm{p}<.01$} \\
\hline \multicolumn{3}{|c|}{$\begin{array}{l}\text { Notes: Random-intercept multilevel logistic regression } \\
\text { models are used in this analysis. }\end{array}$} \\
\hline
\end{tabular}


Table A32: Multilevel Models of Political Participation (2012 LAPOP Survey Data)

\begin{tabular}{lll}
\hline & $(1)$ & $(2)$ \\
& $\begin{array}{l}\text { Electoral } \\
\text { Political } \\
\text { Participation }\end{array}$ & $\begin{array}{l}\text { Non-electoral } \\
\text { Political } \\
\text { Participation }\end{array}$ \\
\hline $\mathrm{CCT}$ & $0.170^{* * *}$ & $0.283^{* * *}$ \\
UCT & 0.026 & -0.234 \\
Income & 0.005 & -0.001 \\
Education & $0.031 * * *$ & $0.070^{* * *}$ \\
Age & $0.562^{* * *}$ & $0.201 * * *$ \\
Female & $-0.104 * * *$ & $-0.250^{* * *}$ \\
Children & $0.089 * * *$ & $0.391^{* * *}$ \\
Religiosity & $0.047 * * *$ & $0.336^{* * *}$ \\
Population & -0.049 & $-0.325^{* * *}$ \\
\hline $\mathrm{N}$ (individual) & 6638 & 7417 \\
$\mathrm{~N}$ (municipality) & 635 & 636 \\
$\mathrm{~N}$ (country) & 9 & 9 \\
\hline$* \mathrm{p}<.10, * * \mathrm{p}<.05, * * * \mathrm{p}<.01$ & \\
Notes: Random-intercept multilevel linear models are used in \\
this analysis.
\end{tabular}


Table A33: Multilevel Models of Political Participation (2012 LAPOP Survey Data)

\section{CCT}

UCT

Income

Education

Age

Female

Children

Religiosity

Population

$\mathrm{N}$ (individual)

$\mathrm{N}$ (municipality)

$\mathrm{N}$ (country)

$* \mathrm{p}<.10, * * \mathrm{p}<.05, * * * \mathrm{p}<.01$
(1)

\section{Contacting}

Public

Officials (alternative measure)

$0.126^{* * * *}$

$-0.051$

$-0.004$

$0.017 * * *$

$0.134 * * *$

$-0.041 * *$

$0.066^{* * * *}$

$0.036 * * *$

$-0.079 * * *$

7749

637

9

9
(2)

(3)

\section{Civil}

Community Society

Activism Engage

(alternative (alternative

measure) measure)

$0.019 \quad 0.022$

$-0.093 \quad 0.008$

$-0.004 * * \quad 0.006 * * *$

$0.008 * * * \quad 0.015 * * *$

$0.070 * * * \quad-0.040 * *$

$-0.057 * * * \quad-0.154 * * *$

$0.062 * * * \quad 0.010$

$0.031 * * * \quad 0.206 * * *$

$-0.041 * *$

$7789 \quad 7752$

$636 \quad 637$

Notes: Random-intercept multilevel linear models are used in this analysis. 
Table A34: Tests of Variance Between Higher-Level Units (2012 LAPOP Survey Data)

\begin{tabular}{lcc}
\hline & $\begin{array}{c}\text { Likelihood- } \\
\text { Ratio Test } \\
\text { Statistic }\end{array}$ & P-value \\
\hline Voting & 992.19 & 0.000 \\
Campaign Activism & 997.62 & 0.000 \\
Contacting Public & & \\
Officials & 321.08 & 0.000 \\
Community Activism & 1075.16 & 0.000 \\
Civil Society Engage & 1342.16 & 0.000 \\
Protest & 246.65 & 0.000 \\
\hline
\end{tabular}

Notes: Likelihood-ratio tests are used for the hypothesis tests in this analysis. The tests analyze variance at the municipality and country levels. 
Table A35: Linear Regression Models of Political Participation (2012 LAPOP Survey Data)

\begin{tabular}{|c|c|c|c|c|c|c|}
\hline & (1) & (2) & (3) & (4) & (5) & (6) \\
\hline & Voting & $\begin{array}{l}\text { Campaign } \\
\text { Activism }\end{array}$ & $\begin{array}{l}\text { Contacting } \\
\text { Public } \\
\text { Officials }\end{array}$ & $\begin{array}{l}\text { Community } \\
\text { Activism }\end{array}$ & $\begin{array}{l}\text { Civil } \\
\text { Society } \\
\text { Engage }\end{array}$ & Protest \\
\hline CCT & 0.026 & 0.140 *** & $0.171^{* *}$ & 0.037 & $0.067 * * *$ & $0.038 * * *$ \\
\hline UCT & 0.015 & 0.004 & -0.053 & -0.155 & -0.029 & 0.097 \\
\hline Income & 0.003 & 0.000 & $-0.008 * *$ & -0.004 & $0.005^{* *}$ & 0.000 \\
\hline Education & $0.015^{* *}$ & $0.015 * * *$ & $0.021 * * *$ & $0.020^{* * *}$ & $0.022 * * *$ & $0.008 * * *$ \\
\hline Age & $0.435^{* *}$ & $0.103^{* *}$ & $0.148^{* *}$ & $0.197 * * *$ & $-0.148 * * *$ & -0.020 \\
\hline Female & 0.004 & $-0.110^{* *}$ & -0.055 & $-0.118^{* *}$ & $-0.073^{*}$ & -0.022 \\
\hline Children & $0.067 * *$ & 0.028 & $0.092 * *$ & $0.100^{* *}$ & $0.247 * * *$ & -0.016 \\
\hline Religiosity & $0.029 * *$ & $0.021^{* *}$ & $0.047 * * *$ & $0.063^{* * *}$ & $0.227 * * *$ & 0.005 \\
\hline Population & -0.040 & -0.017 & $-0.118^{* *}$ & $-0.164 * * *$ & $-0.099 * * *$ & 0.006 \\
\hline $\mathrm{N}$ (individual) & 6753 & 7701 & 7743 & 7673 & 7737 & 7793 \\
\hline
\end{tabular}

$* \mathrm{p}<.10, * * \mathrm{p}<.05, * * * \mathrm{p}<.01$

Notes: Ordinary least squares linear regression models with clustered standard errors are used in this analysis. Dummy variables for countries are included in the models. 